\title{
Renin- és aldoszteronvizsgálat hypertoniás betegekben
}

\author{
Hussein Tamás dr. - Mezősi Emese dr. - Bódis Beáta dr., \\ Nemes Orsolya dr. - Rucz Károly dr. - Bajnok László dr.
}

Pécsi Tudományegyetem, I. Belgyógyászati Klinika, Pécs

A jelen tudományos közleményt a szerzök a Pécsi Tudományegyetem alapitásának 650. évfordulója emlékének szentelik.

\begin{abstract}
Bevezetés: A primer aldosteronismus diagnosztikája bizonytalanságokkal terhelt; legújabban az is felvetődött, hogy a szürésként alkalmazott aldoszteron/renin hányados érzékenysége - a szuppressziós aldoszteron alapján - valójában alacsony. Célkitüzés: A szerzők elsődleges célja az aldoszteron/renin hányados pontosságának vizsgálata volt. Módszer: A retrospektív elemzésben 309 hypertoniás beteg vett részt, akiknél a fekvés és járás után mért aldoszteronszint egymástól függetlenül rendelkezésre állt. Eredmények: Kilencvenkilenc betegnél volt emelkedett az aldoszteron/renin hányados, akik közül 31-nél a fekvő testhelyzetben vizsgált aldoszteron is emelkedett volt. Harmincnégy betegnél a fekvő testhelyzetben vizsgált aldoszteron úgy volt magasabb, hogy az aldoszteron/renin hányados nem; akik közül azonban csak 3 esetben volt alacsony a renin, és így a primer aldosteronismus nem volt elvethető. Kóros reninemelkedés 69 betegnél fordult elő, de csak ezek 59\%-ánál társult magas aldoszteronszinttel. Következtetések: Az aldoszteron/renin hányados érzékenysége magas (91\%), ha csak indokolt esetekben alkalmazzák. Orv. Hetil., 2016, 157(21), $830-835$.
\end{abstract}

Kulcsszavak: hyperaldosteronismus, primer aldosteronismus, aldoszteron/renin hányados, szuppressziós aldoszteron, diagnosztikus határértékek

\section{Renin and aldosterone determinations in hypertensive patients}

Introduction: The diagnostic algorithm of primary aldosteronism is burdened with uncertainties and, recently, it has been suggested that the sensitivity of the aldosterone/renin ratio used as a screening test - based on the suppression aldosterone - is low. Aim: The primary aim was to test the accuracy of aldosterone/renin ratio. Method: In a retrospective analysis of 309 hypertensive patients supine and ambulatory aldosterone levels were independently examined. Results: Aldosterone/renin ratio was elevated in 99 patients of whom 31 exhibited elevated supine aldosterone, as well. In 34 cases supine aldosterone was increased without elevation of the aldosterone/renin ratio. However, only 3 of them had concomitant low renin levels indicating that primary aldosteronism could not be ruled out. Abnormally increased renin was found in 69 patients, but only $59 \%$ of them had increased aldosterone level. Conclusion: Sensitivity of aldosterone/renin ratio is high (91\%) if used only in justified cases.

Keywords: hyperaldosteronism, primary aldosteronism, aldosteron/renin ratio, suppression aldosterone, diagnostic cut-off values

Hussein, T., Mezősi, E., Bódis, B., Nemes, O., Rucz, K., Bajnok, L. [Renin and aldosterone determinations in hypertensive patients]. Orv. Hetil., 2016, 157(21), 830-835.

(Beérkezett: 2015. november 2.; elfogadva: 2016. március 14.) 


\section{Rövidítések}

A = aldoszteron; ACE-I = angiotenzinkonvertálóenzim-gátló; $\mathrm{ARB}=$ angiotenzinreceptor-antagonista; $\mathrm{ARR}=$ aldoszteron $/$ renin hányados; $\mathrm{BB}=$ béta-blokkoló; $\mathrm{C}=$ centrálisan ható szer; $\mathrm{CCB}=$ kalciumcsatorna-blokkoló; NSAID = nem szteroid gyulladásgátló; $\mathrm{PA}=$ primer aldosteronismus; $\mathrm{PRA}=$ plazmarenin-aktivitás; $\mathrm{SA}$ = szuppressziós aldoszteron

A primer aldosteronismus (PA) - az aldoszterontúltermelés autonóm oka - a hypertonia leggyakoribb endokrinológiai és egyik leggyakoribb másodlagos oka. Az esetek több mint 95\%-áért vagy aldoszterontermelő adenoma (aldosteronoma), vagy idiopathiás hyperaldosteronismus (IHA) felelős [1]. PA esetén típusosan vérnyomáscsökkentő szerekkel nehezen befolyásolható, közepesen súlyos vagy súlyos hypertonia alakul ki, s az esszenciális formához képest az érrendszeri szövődmények - így a stroke, szívizominfarktus és ischaemiás vesekárosodás - gyakoribbak, súlyosabbak és korábban jelentkeznek $[2,3]$. A betegséget hypokalaemia is kísérheti [1, 2]. Míg korábban a PA gyakoriságát a hypertoniások körülbelül 1\%-ának gondolták, az utóbbi évek felmérései alapján ezt az értéket általában 10\% körülire becsüljük $[1,2]$, de súlyos, terápiarezisztens hypertoniás betegek körében az arány a $32 \%$-ot is elérheti [4]. A PA irányában szürendő betegek körét illetően nincs teljes egyetértés a vezető szakértők között $[1,5,6]$, de abban a tekintetben konszenzus van, hogy ez nem minden hypertoniás esetében indokolt, viszont (1) a jelentős, valóban terápiarezisztens és/vagy (2) spontán hypokalaemiás forma, illetve (3) mellékvese térfoglaló folyamata társulásakor egyértelmúen megalapozott az indikáció.

PA-ra emelkedett, $15 \mathrm{ng} / \mathrm{dl}$ feletti aldoszteronkoncentráció és alacsony, $1 \mathrm{ng} / \mathrm{ml} / \mathrm{h}$ alatti plazmarenin-aktivitás (PRA) jellemző [6]. E paraméterek hányadosának - az aldoszteron/renin rációnak (ARR) - az alkalmazását javasolja szűrésre az Amerikai Endokrinológiai Társaság (ENDO) algoritmusa [1], amit a hazai endokrinológiai ajánlás is átvett [2]. Általában elfogadott, hogy PA-ra 30 feletti ARR jellemző, de a 20-as határérték is alkalmazható lehet, fóleg akkor, ha nem történt meg előzetesen a lentebb részletezett, álnegatív ARR-t okozó gyógyszerek, így az ACE-gátlók, ARB-k elhagyása. A számolt ARR-értéket az alacsony PRA igen jelentősen növeli, ezért a nevezőben szereplő legalacsonyabb PRA-érték korlátozása indokolt, leginkább elfogadott módon 0,4 ng/ml/h küszöbértékkel. Továbbá a PRA-t csökkentő gyógyszerek szedése, preanalitikai vagy laboratóriumi technikai okok is tehetik félrevezetően magassá az ARR-t $[1,7]$.

A PA diagnosztikus algoritmusában az aldoszteron és PRA ambulanter értékeinek összevetése után a következő kritérium az aldoszterontermelés gátolhatóságának vizsgálata, amit az angiotenzin-II-szint mesterséges szuppressziójával tesztelünk. PA esetén a fokozott al- doszterontermelés alapvetően független a renin-angiotenzin (RAS) hatásától, mégis valamennyi angiotenzinII iránti érzékenység ilyenkor is fenn szokott maradni (aldosteronoma esetében általában kisebb mértékben, mint idiopathiás esetben) $[1,2]$.

A renin- és aldoszteronszintet egyaránt növelő, a diagnosztikát nagyban zavaró hatásuk miatt a mineralokortikoidantagonisták és - ha biztonságosan teljesíthető - egyéb diuretikumok a szűrővizsgálat előtt minimum 4 héttel kihagyandók [1]. Befolyásolják az eredményeket a béta-blokkolók (BB), centrális támadáspontú készítmények (C), nem szteroid gyulladásgátlók (NSAID) is - mind a renin-, mind az aldoszteronszintet csökkentve, az ARR-t pedig növelve -, valamint az angiotenzinkonvertálóenzim-gátlók (ACE-I), angiotenzinreceptor-antagonisták (ARB) és a dihidropiridin típusú kalciumcsatorna-blokkolók (DHP CCB) - a reninszintet növelve, az aldoszteronszintet és így az ARR-t csökkentve. Az alfa-receptor-blokkolók, lassú kioldódású verapamil és hidralazin a renin- és aldoszteronmérések szempontjából semlegesnek tekinthetók. A hypokalaemia csökkenti az aldoszteronelválasztást, legalábbis, ha nem áll fenn aldosteronoma. Utóbbi esetben ugyanis a káliumszint és az aldoszteronelválasztás között fordított összefüggés mutatható ki [8], ami az aldoszteronelválasztás kálium szempontjából is autonóm elválasztására utal.

Egyes szerzők szerint a PA diagnózisához az alacsony renin mellett a nem megfelelően szupprimálódó aldoszteron - ARR-értéktől függetlenül is - elegendő, ami alapján Jansen és mtsai egészében is megkérdőjelezték az ARR mint szưrőmódszer megbízhatóságát [9].

Célkitűzésünk az volt, hogy betegeink között megvizsgáljuk - a renin- és aldoszteroneltérésekkel kapcsolatos betegségek megoszlása mellett - az irodalomban ajánlott különböző határértékek körüli diagnosztikai bizonytalanságokat.

\section{Betegek és vizsgálati módszerek}

Felmérésünk során 309 hypertoniás beteg - 93 férfi (30\%) és 216 nő $(70 \%)$ - adatait elemeztük, retrospektíve, akik osztályos vizsgálatára elsősorban gyógyszer-rezisztencia, mellékvese-incidentaloma vagy hypokalaemia miatt került sor. Átlagéletkoruk $56( \pm 13,5 ; 18-91)$ év volt.

Aldoszteronvizsgálatra elsőként az éjszakai fekvést követően, reggel, 6-7 óra között, felkelés előtt került sor. Ezt tekintettük szuppressziós aldoszteronértéknek. Kétórás reggeli sétát követően ismételten meghatároztuk az aldoszteronkoncentrációt és ezzel együtt mértük a reninaktivitást. Ezek hányadosa, az ARR tehát a járó értékekből került kiszámításra, úgy, hogy a nevezőben alkalmazott legalacsonyabb PRA-érték $0,4 \mathrm{ng} / \mathrm{ml} / \mathrm{h}$ volt. (Az ez alattinak mért értékek helyett egységesen ezen értéket használtuk, mert ily módon az ARR jól harmonizál az aldoszteron-határértékkel [7].) Mivel vizsgálatainkat a betegbiztonság elsődlegessége mellett végeztük, 
első körben csak a diuretikumok helyettesítésére törekedtünk, az egyéb zavaró gyógyszerek (elsősorban RASgátlók) ARR-t (és a PA szürésének érzékenységét potenciálisan) csökkentő hatását alacsonyabb ARR-határérték alkalmazásával $(20 \mathrm{ml} \cdot \mathrm{h} / \mathrm{dl})$ ellensúlyoztuk, ami az ARR érzékenységét fokozza.

A reninvizsgálatokra a mintákat jégben tárolva juttattuk el a laboratóriumba, ahol a mintákat -20 Celsius-fokon tárolták a meghatározásokig. Az aldoszteronkoncentráció és a reninaktivitás in vitro laboratóriumi meghatározása radioimmunoassay (RIA) alkalmazásával történt (Beckman Coulter).

A statisztikai feldolgozást IBM SPSS 22.0 szoftver segítségével végeztük. Az adatok eloszlásának normalitását Kolmogorov-Smirnov-teszt, a szedett gyógyszerek és hormonszintek közötti kapcsolatot kétmintás (független) T-próba alkalmazásával elemeztük. Ötszázalékos küszöböt alkalmaztunk a szignifikancia meghatározásakor.

\section{Eredmények}

Sem az aldoszteronszint, sem a PRA nem volt normáleloszlású. A fekvő (szuppressziós) aldoszteronkoncentráció átlagosan $45 \%$-kal volt alacsonyabb, mint a kétórás járást követő aldoszteronérték ( 9,4 vs. 17,3 ng/dl). A fekvés utáni 8,5 és $10 \mathrm{ng} / \mathrm{dl}$ közötti aldoszteronértékeket átmeneti zónának tekintettük. Mindössze 102 beteg (a vizsgáltak 33\%-a, 30 férfi és 72 nő) volt teljesen negatívnak tekinthető $(\mathrm{ARR}<20 \mathrm{ml} \cdot \mathrm{h} / \mathrm{dl}$, a járást követő aldoszteronszint 3,4-15 ng/dl és a fekvés utáni aldoszteronértékek $1-8,5 \mathrm{ng} / \mathrm{dl}$ közötti).

Hatvankilenc betegnél (a vizsgált betegek 22\%-ánál, 13 férfi és 18 nő) volt emelkedett a járást követő PRA (>5 ng/ml/h). Ezen hyperreninaemiás betegek 59\%ánál volt szekunder hyperaldosteronismus is megállapítható az aldoszteronszint járást (>15 ng/dl) és/vagy fekvést (>10 ng/dl) követően magas volta alapján (1.ábra).

Kilencvenkilenc beteg (az összes beteg 32\%-a, 35 férfi, 64 nő) esetében az ARR emelkedett, $20 \mathrm{ml} \cdot \mathrm{h} / \mathrm{dl}$ feletti volt. Ezen betegek szuppressziós aldoszteronérték-meg-

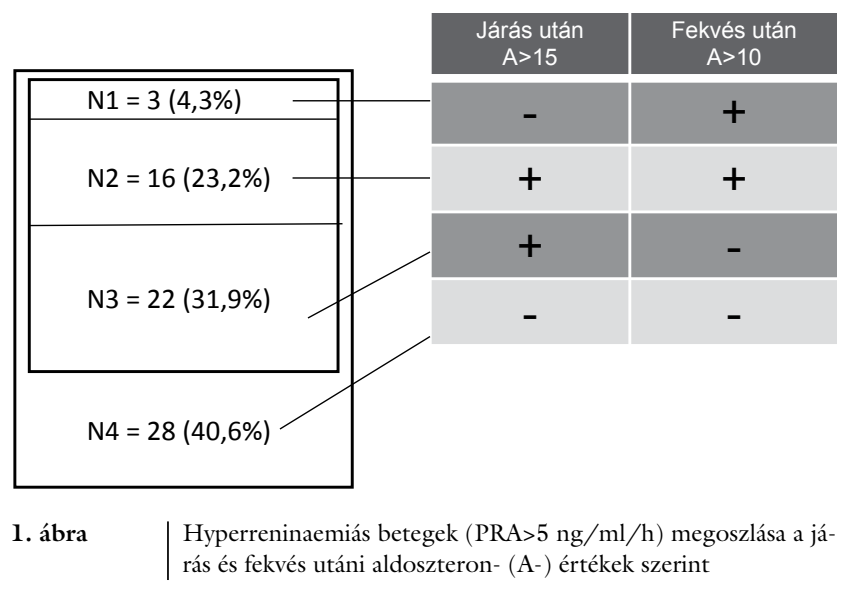

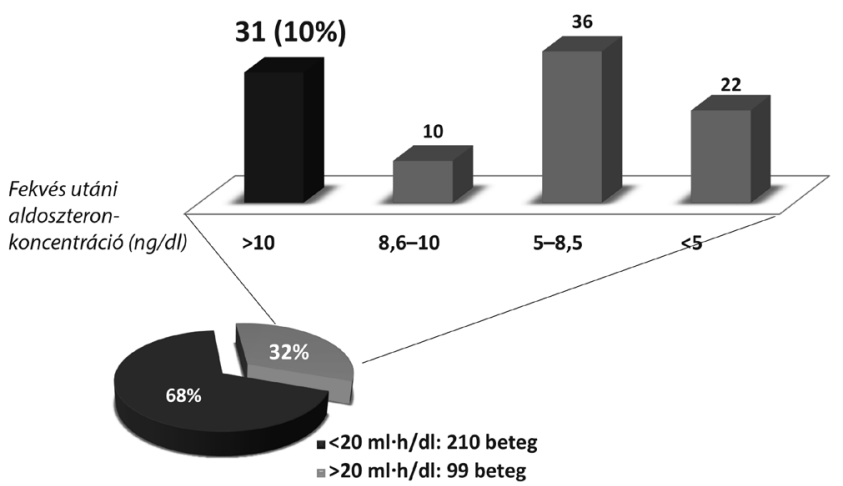

2. ábra $\mid$ Az emelkedett $(20 \mathrm{ml} \cdot \mathrm{h} / \mathrm{dl}$ feletti) ARR-értékű betegek fekvés utáni aldoszteronértékeinek megoszlása

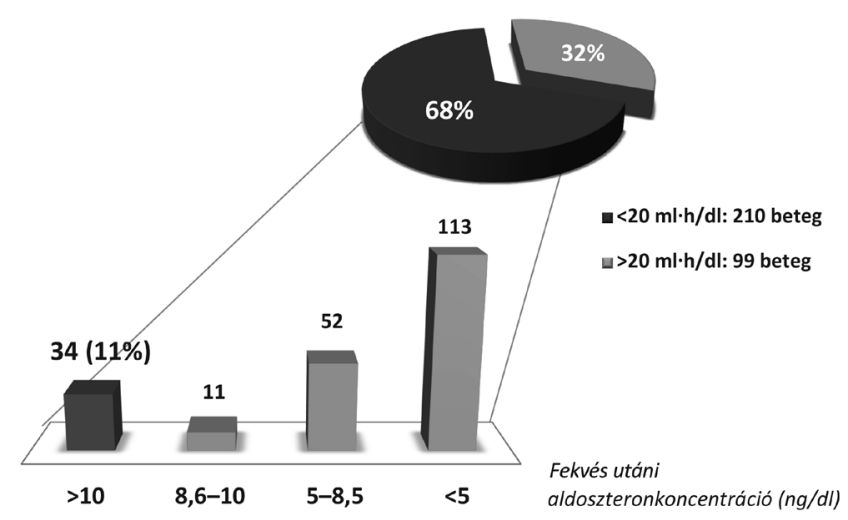

3. ábra $\quad$ A normális $(20 \mathrm{ml} \cdot \mathrm{h} / \mathrm{dl}$ alatti $)$ ARR-értékű betegek fekvés utáni aldoszteronértékeinek megoszlása

oszlását a 2. ábrán tüntettük fel; kiemelendő, hogy a szuppressziós aldoszteron PA-ra jellemzően emelkedett (10 ng/dl feletti) maradt 31 esetben (az összes beteg 10\%-a, 13 férfi, 18 nő). Külön vizsgáltuk a $20 \mathrm{ml} \cdot \mathrm{h} / \mathrm{dl}$ határ alatti ARR-értékű betegek szuppressziós aldoszteronértékeinek a megoszlását (3. ábra). Ez magas arányban, 34 betegnél volt emelkedett (>10 ng/dl), de ezek közül 19 esetben a PRA is magas volt $(5 \mathrm{ng} / \mathrm{ml} / \mathrm{h}$ feletti), tehát nem primer, hanem szekunder hyperaldosteronismus állhatott a háttérben. Azonban a fennmaradó 15 kérdéses esetből is csak háromnál volt reális a $\mathrm{PA}, \mathrm{az}$ alacsony $(<\mathrm{lng} / \mathrm{ml} / \mathrm{h})$ PRA alapján. Az ARR érzékenysége tehát $31 /(31+3)=0,912$ lett, ha csak a PRA $<1$ ng $/$ $\mathrm{ml} / \mathrm{h}$ értékű beteget elemeztük. Az alacsony PRA-értékü (<l ng/ml $/ \mathrm{h}$ ) betegek megoszlását az 1. táblázatban tüntettük fel. E csoport esetén egyébként az ARR fajlagossága is viszonylag magas volt $(54 / 92=0,587$; az irodalom általános betegpopulációin ez 0,30 körüli).

Mindössze egy olyan beteget találtunk, akinél az ARR ugyan $20 \mathrm{ml} \cdot \mathrm{h} / \mathrm{dl}$ alatti volt, de a Kaplan-kritériumok alapján [6] az aldoszteronszint emelkedett (>15 ng/dl) és a PRA egyidejúleg alacsony $(1 \mathrm{ng} / \mathrm{ml} / \mathrm{h}$ alatti) volt; azonban az aldoszteron e beteg esetében is megfelelően (nem PA-ra jellemző, 10 ng/dl alatti értékre) szupprimálódott. 
1. táblázat $\mid \mathrm{Az}$ alacsony PRA-értékü $(<\mathrm{lng} / \mathrm{ml} / \mathrm{h})$ betegek megoszlása $(\mathrm{n}=126)$ az ARR- és fekvés utáni aldoszteron- (A-) értékek szerint

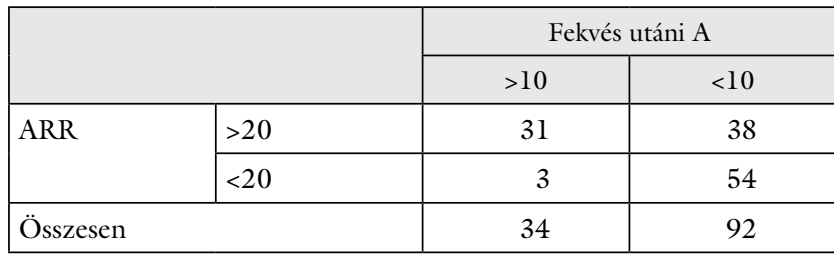

2. táblázat |Az adott gyógyszer és a hormonszint közötti kapcsolat

\begin{tabular}{lcccc}
\hline Gyógyszerek & Betegszám & \multicolumn{3}{c}{ Hormonok } \\
\cline { 3 - 5 } & & $\begin{array}{c}\text { Fekvés } \\
\text { utáni A }\end{array}$ & Renin & $\begin{array}{c}\text { Járás } \\
\text { utáni A }\end{array}$ \\
\hline Diuretikumok & 56 & $\leftarrow \rightarrow$ & $\uparrow$ & $\leftarrow \rightarrow$ \\
ACE-I, ARB, CCB & 259 & $\downarrow$ & $\uparrow$ & $\downarrow$ \\
BB, C & 166 & $\downarrow$ & $\downarrow$ & $\downarrow$ \\
NSAID & 25 & $\downarrow$ & $\leftarrow \rightarrow$ & $\leftarrow \rightarrow$ \\
K & 74 & $\leftarrow \rightarrow$ & $\uparrow$ & $\uparrow$ \\
\hline
\end{tabular}

$\uparrow=$ pozitív $\downarrow \downarrow=$ negatív $\leftrightarrow \leftrightarrow$ = hiányzik; ACE-I = angiotenzinkonvertálóenzim gátló; $\mathrm{ARB}=$ angiotenzinreceptor-antagonista; $\mathrm{BB}=$ béta-blokkoló; $\mathrm{C}=$ centrá lisan ható szer; $\mathrm{CCB}=$ kalciumcsatorna-blokkoló; NSAID = nem szteroid gyulladásgátló.

Három beteg (a vizsgáltak 1\%-a) volt hyporeninaemiás-hypoaldosteronismusos csoportba sorolható, a csökkent PRA $(<0,4 \mathrm{ng} / \mathrm{ml} / \mathrm{h})$ és aldoszteronszint (járás után $<3,4 \mathrm{ng} / \mathrm{dl}$, a fekvést követően $<1 \mathrm{ng} / \mathrm{dl}$ ) alapján.

A vizsgálatkor szedett zavaró gyógyszerek és a mért hormonszintek közötti összefüggéseket a 2. táblázatban összegeztük. Kiemelendő, hogy a diuretikumok nem voltak statisztikailag szignifikáns kapcsolatban az aldoszteronszintekkel, de szedésük magasabb PRA-val társult. A várakozásoknak megfelelően az ACE-I-et és/ vagy $A R B-t$ és/vagy DHP CCB-t szedő betegcsoport esetében alacsonyabb aldoszteronszinteket és magasabb reninaktivitást találtunk. A BB és/vagy centrális támadáspontú szerek (C) szedése mellett a vizsgált hormonok értékei alacsonyabbak voltak. Az NSAID statisztikailag szignifikáns (negatív) korrelációban csak a szuppressziós aldoszteronszinttel volt. A káliumszedés ténye és a járás után mért aldoszteronszint, illetve reninaktivitás között pozitív kapcsolatot lehetett kimutatni.

\section{Megbeszélés}

A PA diagnózisának alapvető problémáját jelenti a kórisme alapját képező „arany standard” hiánya. Ezért a szürö- és szuppressziós tesztek érzékenységének és fajlagosságának számításakor ezen hormonális értékeket is figyelembe kell venni, egyéb paraméter(ek) mellett [10]. Az utóbbiak közül IHA esetén azonban csak a terápiás válasz jön szóba. (A mellékvese térfoglaló folyamata kép- alkotó és/vagy hisztológiai vizsgálattal történő kimutatása itt nem realitás.) A tesztek ilyen módon számított érzékenysége és fajlagossága sem optimális, aminek példája, hogy a PA-esetek 10\%-ában a diagnózis megerősítésére szolgáló sóinfúzió utáni aldoszteronérték az egyértelműen negatívnak tekintett $5 \mathrm{ng} / \mathrm{dl}$ küszöb alatt van. Tehát ezen legszenzitívebb kritérium mellett is csak $90 \%$ a sóinfúziós teszt érzékenysége; magasabb küszöbértékeket alkalmazva pedig az érzékenység meredeken csökken [10]. A bizonytalanságot jelzi, hogy legújabban is vannak, akik a sóinfúzió hatásának megítélésére a régi, $8,5 \mathrm{ng} / \mathrm{dl}$ határértéket tekintik mérvadónak $[9,11]$. Helyesebb lehet, ha még küszöb alatti szuppressziós aldoszteronértékü betegek esetén is inkább csak egyre csökkenő valószínúséggel beszélünk PA-ról (ami - mint fentebb jeleztük - még az $5 \mathrm{ng} / \mathrm{dl}$ alatt sem vethető el teljesen). Ennek elsődleges jelentősége az, hogy ha a PA gyanúja kellően megalapozott, mellékvese-CT (esetleg -MR) indikált, ami, ha térfoglaló folyamatot igazol, glükokortikoidszuppressziós ${ }^{131}$ I norkoleszterin SPECT-et - lehetőleg röntgen-CT-vel kombinált formában - tehet indokolttá. Megfelelő központokban a mellékvese szelektív vénás mintavétele is szóba jöhet, elsősorban akkor, ha a $\mathrm{CT} / \mathrm{MR}$ negatív.

A hazai gyakorlatban szuppressziós vizsgálatként - a sóinfúzió mellett - captoprilteszt is végezhető, ambulanter körülmények között is $[1,12]$. Az általunk alkalmazott, tartós fekvést követően mért aldoszteronérték is szuppressziósnak felel meg; ilyenkor a fiziológiásan megfelelően csökkenő PRA-t használjuk a differenciálásra. A módszer érzékenysége a captopriltesztéhez hasonlatos, fajlagossága valamivel alacsonyabb [13]. Igaz, hátránya, hogy hospitalizációt igényel. Mivel a fekvés szuppressziós hatása a sóinfúzióénál kevésbé kifejezettnek tekinthető [10], küszöbértékként nem a fent jelzett és „normálhatárként” is alkalmazott $8,5 \mathrm{ng} / \mathrm{dl}$-t, hanem $10 \mathrm{ng} / \mathrm{dl}$-t alkalmaztunk a fekvő aldoszteron megítélésekor. Ennek validitása mellett szól, hogy az általunk alkalmazott ambulanter ARR-határérték $(20 \mathrm{ml} \cdot \mathrm{h} / \mathrm{dl})$ feletti betegeink 10\%-ánál ( 31 beteg) volt PA-ra jellemzően magas ezen szuppressziós aldoszteronszint, ami igen hasonló a sóinfúzióval végzett PAPY vizsgálatban talált 11,2\%-os arányhoz. Hangsúlyozni kell, hogy a testhelyzetnek a vizsgált hormonokra gyakorolt hatását nem posturalis/stimulációs tesztként értékeltük, ami az aldoszterontermelő adenoma és az idiopathiás forma elkülönítésére alkalmazható - elsősorban akkor, ha a mellékvese szelektív vénás katéterezése nem elérhető, sikertelen, vagy eredménye nem egyértelmú $[2,12]$. Amennyiben ugyanis a PA-kritériumok teljesülnek ugyan, de a fekvő aldoszteronérték lényegesen kisebb, mint a posturalis, az IHA mellett (és aldosteronoma ellen) szól, ellenkező esetben viszont rejtett, CT-n nem ábrázolódó, aldosteronomagyanús, és megfontolható olyan ellátóhelyre irányítás, ahol ez a vizsgálat sikerrel szokott történni. Hazánkban ugyanis ritkán végzett vizsgálat a mellékvese 
szelektív vénás katéterezés, és - saját tapasztalatunk alapján - különösen ritkán sikeresen.

Magunk is végezzük a sóinfúziós tesztet az aldoszteron szuppressziójára, de elsősorban azokban a bizonytalan esetekben, amikor az ARR>20 ml·h/dl és a fekvés utáni aldoszteronkoncentráció 8,5 és 10 ng/dl közötti (a felett a PA valószínúsége olyan tartományba emelkedik, ahol CT-t indikálunk), de ezek az adatok, korlátozott voltuk miatt, nem relevánsak a jelen elemzésben.

Mindössze egy olyan beteget találtunk, akinél az ENDO-ajánlás szerint nem került volna sor további vizsgálatra az ARR $20 \mathrm{ml} \cdot \mathrm{h} / \mathrm{dl}$ alatti értéke miatt, de a Kaplan-kritériumok (aldoszteron $>15 \mathrm{ng} / \mathrm{dl}+\mathrm{PRA}<\mathrm{l} \mathrm{ng} /$ $\mathrm{ml} / \mathrm{h}$ ) alapján igen [6]. Szerencsésnek tekinthető, hogy ezeknél a betegnél is $10 \mathrm{ng} / \mathrm{dl}$ alatti, nem PA-ra jellemző volt a szuppressziós aldoszteron.

A PA diagnosztikáját más oldalról komplikálja Jansen és munkatársainak az a friss feldolgozása, ami szerint a sóinfúzió után mért aldoszteronértékre alkalmazott 8,5 ng/dl küszöbérték mellett az ENDO által ajánlott ARRérték érzékenysége igen alacsony, mindössze 22\% [9]. Ez azt sugallja, hogy a PA-betegek nagy része az ambulanter ARR-szưrés után nem is kerül további kivizsgálásra. Ezért magunk is elemeztük a nem magas ARR-értéküek (<20 ml.h/dl) szuppressziós aldoszteronszintjét. Bár ezt magas arányban, 34 beteg esetében találtuk emelkedettnek (>10 ng/dl), mindössze három betegnél volt a PRA olyan alacsony $(<1 \mathrm{ng} / \mathrm{ml} / \mathrm{h})$, hogy PA diagnózis reális legyen. Ezek alapján 91\%-nak találtuk az ARR érzékenységét, és nem tudjuk megerösíteni Jansen és munkatársainak aggodalmát a PA ARR-rel történő szúrhetőségét illetően.

Vizsgálatunk legnagyobb előnyének az tekinthető, hogy a szuppressziós teszt - aminek a validitása bizonyos mértékig ugyan vitatható lehet - az ambulanter szüréstől (ARR-től) függetlenül megtörtént, ezáltal az ARR érzékenységét vizsgálhatóvá tette. Az eredmények általánosíthatóságát valamelyest csökkentheti még, hogy a hormonmeghatározások általában ezt befolyásoló - bár az ENDO-irányelv szerint megengedett [1] - gyógyszerek, elsősorban RAS-gátló és/vagy CCB, másodsorban bétablokkoló és/vagy centrális szer hatásában történtek. (A vizsgált betegek 18\%-ában, 56 betegnél a diuretikum ajánlás szerinti kihagyása sem történt meg, elsősorban azért, mert ez orvosi szempontból kockázatosnak ítéltetett.) Mindamellett, az általunk alkalmazott ARR-határérték $(20 \mathrm{ml} \cdot \mathrm{h} / \mathrm{dl})$ mellett azonos arányban (32\%) találtunk emelkedett értéket, mint a Bussolengo vizsgálatban, ahol a vizsgáltak csak verapamilt és alfa-blokkolót kaphattak, és az ARR-határ 50 volt [14]. Másrészt - mint arra Tanabe és munkatársainak elemzése rámutatott az aldoszteron- és reninszint aldosteronomában kimutatható nagyfokú intraindividuális variabilitása nem magyarázható a standard körülmények hiányával, mert ezek legnagyobb gondossággal történő biztosítása mellett is többszörös ingadozás mutatható ki a renin- és aldoszteronszintekben, ugyanakkor a random és standar- dizált vizsgálatok variabilitása nem különbözik érdemben [8]. Mindez az aldosteronoma szekréciójának inherensen epizodikus jellegére utal, amit következményesen a reninaktivitás ellentétes irányú változása kísér.

Tanulmányunk fó gyengesége, hogy a terápiás eredmények elemzésére nem terjed ki.

A káliumszedés anamnézisben szereplő ténye és a járás után mért aldoszteronszint, illetve reninaktivitás közötti pozitív összefüggés feltételezhetően annak a következménye, hogy a hypertoniáért is felelős emelkedett PRA és aldoszteronszint a káliumürítést is fokozhatja, amit gyakrabban kell külön is pótolni, és nem maga a káliumpótlás emelte ezeknek a hormonoknak a szintjét.

$\mathrm{Az}$ aldoszteron- és reninszintek vizsgálata további, a terápiát befolyásoló csoportosítást is lehetővé tett a vizsgált hypertoniás populáción belül. Így általában nem javasolt kombinált RAS-blokád - ACE-I és ARB, esetleg a direkt renininhibitor aliskiren együttes alkalmazása -, de egyéb terápiára abszolút rezisztens hyperreninaemiás hypertoniások esetén mégis megfontolható lehet, akkor is, ha ez a vesefunkció alakulása szempontjából nem előnyös $[15,16]$. Ilyenkor a spironolacton kevésbé hatásos, mint alacsonyabb reninérték esetén [17, 18]. Saját hyperreninaemiás betegeink közel felében a (járást követő) aldoszteronszint nem volt emelkedett, tehát nem lehetett szekunder hyperaldosteronismusról beszélni. Ennek magyarázata az lehet, hogy ACE-I vagy ARB, kisebb mértékben a DHP CCB csökkenti az AT-II-szintet vagy -hatást, „belsőleg szétkapcsolva” a RAAS-t.

A rezisztens hypertoniások lehetséges ellátási algoritmusát a 4. ábrán tüntettük fel.

Hyporeninaemiás hypoaldosteronismus esetében olyan ritka kórképekre is gondolni kell, mint DOC(11-dezoxikortikoszteron-) túltermelés (DOC-oma, 11$\beta$-vagy 17- $\alpha$-hidroxiláz defektus okozta congenitalis adrenalis hyperplasia), Liddle-kór (epithelialis Na-csatorna

ACEi / ARB + CCB + D ellenére rezisztens HT

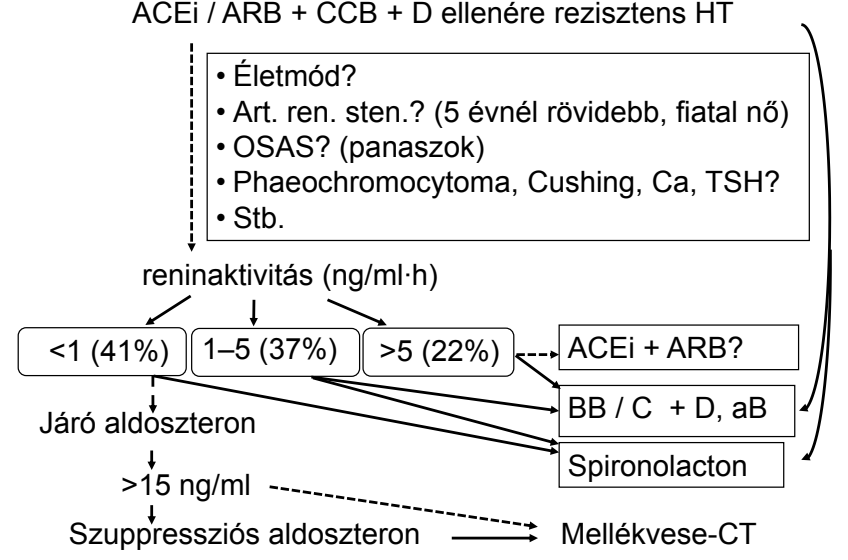

4. ábra $\quad$ Rezisztens hypertoniások lehetséges ellátási algoritmusa folyamatos vonal = szokásos; szaggatott vonal = fakultatív; $\mathrm{aB}=$ alfa ${ }_{1}$-blokkoló; $\mathrm{ACEi}=$ angiotenzinkonvertálóenzim-gátló; $\mathrm{ARB}=$ angiotenzinreceptor-antagonista; $\mathrm{BB}=$ béta-blokkoló; $\mathrm{C}=$ centrálisan ható szer; $\mathrm{CCB}=$ kalciumcsatorna-blokkoló; OSAS = obstruktív alvási apnoe 
konstitutív aktiválódása), továbbá Cushing-szindróma, kortizolrezisztencia és a látszólagos mineralokortikoidtúlsúly.

\section{Következtetések}

A renin- és aldoszteronvizsgálatok szélesebb körü alkalmazása a hypertonia jobb kezelhetőségét eredményezheti. Érdemes azonban figyelembe venni, hogy a primer aldosteronismus diagnosztikája bizonytalanságokkal terhelt, többek között azért, mert a hormonhatárértékek - így a PA esetén emelkedettnek tartott aldoszteron/ renin hányados, az ARR - pontosságának számításakor maguk ezen vizsgált paraméterek is referenciakritériumként szerepelnek. Célszerúbb lehet egy, a primer aldosteronismus diagnózisát inkább valószínúségi jelleggel alkalmazó megközelítés, amiben a betegeket kis, közepes (bizonytalan) és nagy valószínúségű kategóriákba sorolva jobban lehet segíteni a további diagnosztikus és terápiás döntéshozatalt. Azokban az esetekben, ahol a PA valószínúsége az átlagos rezisztens hypertoniásokénál nagyobb, a spironolacton indikációja is határozottabb, míg a hyperreninaemiás formák esetén egyéb kombinált RAS-blokád is szóba jöhet. Tehát a hyper- vagy hyporeninaemia igazolása is terápiás útmutatást adhat.

Anyagi támogatás: A közlemény megírása és a kapcsolódó kutatómunka anyagi támogatásban nem részesültt.

Szerzői munkamegosztás: B. L., M. E.: A hipotézisek kidolgozása. H. T., M. E., B. B., N. O., R. K., B. L.: A vizsgálat lefolytatása. H. T., M. E.: Statisztikai elemzések. H. T., B. L., M. E.: A kézirat megszövegezése. A cikk végleges változatát valamennyi szerző elolvasta és jóváhagyta.

Érdekeltségek: A szerzőknek nincsenek érdekeltségeik.

\section{Irodalom}

[1] Funder, J. W., Carey, R. M., Fardella, C., et al.: Case detection, diagnosis, and treatment of patients with primary aldosteronism: an endocrine society clinical practice guideline. J. Clin. Endocrinol. Metab., 2008, 93(9), 3266-3281.

[2] Hungarian Society for Endocrinology and Metabolism: Metabolic guide for primer hyperaldosteronism. [Magyar Endokrinológiai és Anyagcsere Társaság: Anyagcsere-útmutató; Primer hyperaldoszteronismus.] Medition Kiadó, Budapest, 2010. [Hungarian]

[3] Szücs, N., Glàz, E., Varga, I., et al.: Diagnosis and treatment outcome in primary aldosteronism based on a retrospective analysis of 187 cases. [A primer aldosteronismus diagnosztikája és a keze- lés eredményei 187 beteg adatainak retrospektív elemzése alapján.] Orv. Hetil., 2006, 147(2), 51-59. [Hungarian]

[4] Rayner, B. L., Opie, L. H., Davidson, J. S.: The aldosterone/renin ratio as a screening test for primary aldosteronism. S. Afr. Med. J., 2000, 90(4), 394-400.

[5] Kaplan, N. M.: Primary aldosteronism: evidence against a second epidemic. J. Hypertens., 2012, 30(10), 1899-1902.

[6] Kaplan, N. M., Victor, R. G.: Kaplan's Clinical Hypertension. Eleventh Edition. Wolters Kluwer, 2015.

[7] Rossi, G. P., Bernini, G., Caliumi, C., et al.: A prospective study of the prevalence of primary aldosteronism in 1,125 hypertensive patients. J. Am. Coll. Cardiol., 2006, 48(11), 2293-2300.

[8] Tanabe, A., Naruse, M., Takagi, S., et al.: Variability in the renin/ aldosterone profile under random and standardized sampling conditions in primary aldosteronism. J. Clin. Endocrinol. Metab., 2003, 88(6), 2489-2494.

[9] Jansen, P. M., van den Born, B. J., Frenkel, W. J., et al.: Test characteristics of the aldosterone-to-renin ratio as a screening test for primary aldosteronism. J. Hypertens., 2014, 32(1), 115-126.

[10] Rossi, G. P., Belfiore, A., Bernini, G., et al.: Prospective evaluation of the saline infusion test for excluding primary aldosteronism due to aldosterone-producing adenoma. J. Hypertens., 2007, 25(7), 1433-1442.

[11] Streeten, D. H., Tomycz, N., Anderson, G. H.: Reliability of screening methods for the diagnosis of primary aldosteronism. Am. J. Med., 1979, 67(3), 403-413.

[12] Bajnok, L.: How could be the treatment of endocrine hypertensions improved? [Hogyan lehetne javítani az endokrin hypertoniák kezelésének a helyzetén?] Hypertonia és Nephrologia, 2009, 13(1), 11-21. [Hungarian]

[13] Hambling, C., Jung, R. T., Gunn, A., et al.: Re-evaluation of the captopril test for the diagnosis of primary hyperaldosteronism. Clin. Endocrinol. (Oxf.), 1992, 36(5), 499-503.

[14] Olivieri, O., Ciacciarelli, A., Signorelli, D., et al.: Aldosterone to renin ratio in a primary care setting: the Bussolengo study. J. Clin. Endocrinol. Metab., 2004, 89(9), 4221-4226.

[15] Bajnok, L.: Lessons from the novel renoprotective studies made by antihypertensive drugs. [Mire tanítanak a vérnyomáscsökkentőkkel végzett újabb renoprotektív vizsgálatok?] Orv. Hetil., 2013, 154(7), 243-247. [Hungarian]

[16] $2013 \mathrm{ESH} / \mathrm{ESC}$ Guidelines for the management of arterial hypertension. The Task Force for the Management of Arterial Hypertension of the European Society of Hypertension (ESH) and of the European Society of Cardiology (ESC). Eur. Heart J., 2013, 34(28), 2159-2219.

[17] Václavík, J., Sedlák, R., Plachy, M., et al.: Addition of spironolactone in patients with resistant arterial hypertension (ASPIRANT): a randomized, double-blind, placebo-controlled trial. Hypertension, 2011, 57(6), 1069-1075.

[18] Williams, B., MacDonald, T. M., Morant, S., et al.: Spironolactone versus placebo, bisoprolol, and doxazosin to determine the optimal treatment for drug-resistant hypertension (PATWAY-2): a randomised, double-blind, crossover trial. Lancet, 2015, 386(10008), 2059-2068.

(Bajnok László dr., Pécs, Ifjúság u. 13., 7624 e-mail: bajnok.laszlo@.pte.hu) 